\title{
Synthesis, Structure, and Reactivity of Disiloxa[3]tetrelocenophanes
}

\author{
Lisa Wirtz, Matthias Jourdain, Volker Huch, Michael Zimmer, and André Schäfer*i)
}

Faculty of Natural Sciences and Technology, Department of Chemistry, Saarland University, Campus Saarbrücken, 66123 Saarbrücken, Federal Republic of Germany

\section{Supporting Information}

ABSTRACT: Tetramethyldisiloxa[3]metallocenophanes of the heavy group 14 elements germanium, 2a, tin, $\mathbf{2 b}$, and lead, $\mathbf{2 c}$, (tetrelocenophanes) have been synthesized by the reaction of dilithiated ligand, $\mathbf{1}$, with the corresponding element(II) chloride. The plumbocenophane, $\mathbf{2 c}$, forms one-dimensional coordination polymers in the solid state, while the germanocenophane, $\mathbf{2} \mathbf{a}$, and the stannocenophane, $\mathbf{2} \mathbf{b}$, are monomeric. Furthermore, the reactivity of the stannocenophane, $\mathbf{2 b}$, and the plumbocenophane, $\mathbf{2 c}$, toward $\mathrm{N}$ -

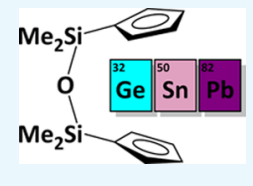
heterocyclic carbenes was explored. Although the coordination of carbene is reversible in solution at room temperature, the corresponding carbene complexes, $\mathbf{3} \mathbf{a}, \mathbf{b}$, could be structurally characterized, illustrating the Lewis acidity of the central atom in these metallocenophanes.

\section{INTRODUCTION}

Metallocenes with interlinked cyclopentadienyl moieties, so called ansa-metallocenes or metallocenophanes, have been known for over half a century, with examples for various transition metals. ${ }^{1}$ They have attracted wide attention for their applications as catalysts in homogeneous catalysis or as monomers in ring-opening polymerization reactions. ${ }^{2,3}$ In contrast, metallocenophanes of p-block elements are much less common, with only a handful of structurally characterized examples, mostly of group 14 elements (tetrelocenophanes). ${ }^{4-10}$ This is particularly surprising, as the unbridged parent compounds have been known for a long time, ${ }^{11-13}$ with stannocene and plumbocene being the first diorganotetrylene type compounds described in the literature. ${ }^{14,15}$ Furthermore, these species could be of potential interest as precursors in the preparation of p-block metal-containing oligomers and polymers. With the great progress in low-valent group 14 chemistry in recent years, ${ }^{16-19}$ and our group's interest in the main group element-based metallocenophanes, our aim was to investigate the influence of different bridging motifs on the molecular geometry and reactivity of tetrelocenophanes. Whereas previous studies focused on disila[2]metallocenophanes, ${ }^{9,10,20}$ we now report the first synthesis and structural characterization of three-atomic bridged metallocenophanes of p-block elements, in the form of disiloxa[3]tetrelocenophanes of group 14 elements germanium, tin, and lead, 2a-c. Although the tetramethyldisiloxa[3] bridging motif has been employed in transition metal-based metallocenophanes in the past, ${ }^{21-26}$ no p-block metallocenophanes with three-atomic bridging motifs have been reported, so far.

\section{RESULTS AND DISCUSSION}

The reaction of dilithiated ligand 1 with the corresponding element(II) chloride proceeds smoothly at $173 \mathrm{~K}$ to give the corresponding [3] tetrelocenophanes, $\mathbf{2 a}-\mathbf{c}$, in good yields (Scheme 1). Stannocenophane, $\mathbf{2 b}$, and plumbocenophane, $\mathbf{2 c}$, exhibit very upfield-shifted NMR resonances in the ${ }^{119} \mathrm{Sn}$ and ${ }^{207} \mathrm{~Pb}$ NMR spectra, respectively, $\left(\delta^{119} \mathrm{Sn}(\mathbf{2 b})=-2124\right.$;
Scheme 1. Synthesis of

Tetramethyldisiloxa[3] tetrelocenophanes, 2a-c [a: E = Ge, $D=1,4$-dioxane; $b: E=S n, D=t h f ; c: E=P b, D=t h f]$
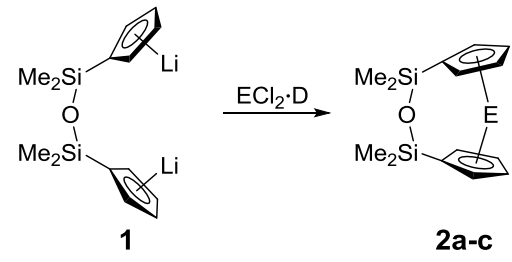

a: $\mathrm{E}=\mathrm{Ge}(82 \%)$

b: $E=S n(70 \%)$

c: $E=P b(54 \%)$

$\left.\delta^{207} \mathrm{~Pb}(2 \mathrm{c})=-4795\right)$, as is typical for tin(II)- and lead(II)based metallocenes. ${ }^{9,10}$

Crystals suitable for single crystal X-ray diffraction analysis were obtained from hexane solutions at $248 \mathrm{~K}$, allowing for a structural characterization of tetrelocenophanes 2a-c (Figure 1).

While germanocenophane, $\mathbf{2 a}$, and stannocenophane, $\mathbf{2 b}$, are monomeric in the solid state, plumbocenophane, $2 c$, exhibits a one dimensional polymeric structure in the crystal in which each lead atom is coordinated by three cyclopentadienyl ligands, similar to what is found for plumbocene $\left(\mathrm{Cp}_{2} \mathrm{~Pb}\right)$ in the solid state, ${ }^{27-29}$ and unlike what was reported earlier for a permethylated $\mathrm{Si}[2]$ plumbocenophane. ${ }^{9}$ The intermolecular $\mathrm{Pb}-\mathrm{C}^{\mathrm{CP}}$ distances are longer $(337.9-395.1 \mathrm{pm})$ than the intramolecular ones $(243.0-256.0 \mathrm{pm})$, suggesting rather weak intermolecular interactions, which is in line with the assumption that plumbocenophane, $2 \mathrm{c}$, is monomeric in solution. The metal-Cp bonds in $2 \mathbf{a}-\mathbf{c}$ are within normal ranges for group 14 metallocenes. ${ }^{10}$ When comparing the dihedral angles of the $\mathrm{Cp}$ planes, $\alpha$, in [3]tetrelocenophanes $2 \mathbf{a}-\mathbf{c}$ to the angles $\alpha$ found in the previously reported permethylated [2] tetrelocenophanes, ${ }^{9}$ one conspicuous differ-

Received: August 13, 2019

Accepted: September 30, 2019

Published: October 21, 2019 
a)

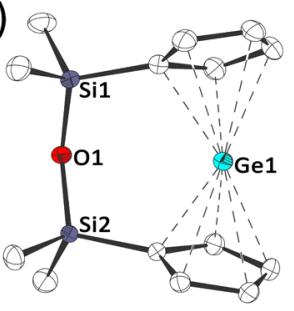

b)

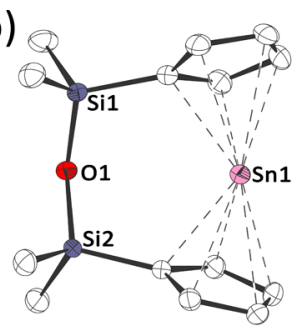

c)

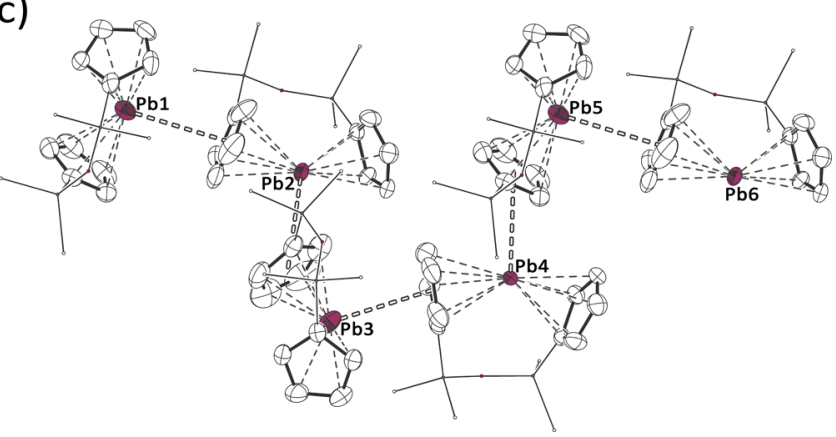

Figure 1. Molecular structures of (a) 2a, (b) 2b, and (c) 2c in the crystal (thermal ellipsoids at $50 \%$ probability level, except for the ansa-bridge of $2 \mathrm{c}$ in (c); $\mathrm{H}$ atoms omitted for clarity).

ence is that [3] tetrelocenophanes $\mathbf{2 a}-\mathbf{c}$ exhibit a more bent geometry, much like the unbridged parent compounds germanocene $\left(\mathrm{Cp}_{2} \mathrm{Ge}\right),{ }^{30}$ stannocene $\left(\mathrm{Cp}_{2} \mathrm{Sn}\right),{ }^{31}$ and plumbocene $\left(\mathrm{Cp}_{2} \mathrm{~Pb}\right) .^{27-29}$ This is because of the stereochemically active lone pair at the central atom. The influence of the $\mathrm{Si}-$ $\mathrm{O}-\mathrm{Si}$ ansa-bridge in tetrelocenophanes $2 \mathrm{a}-\mathrm{c}$ on the dihedral angle of the Cp-planes, $\alpha$, is comparably small (Table 1 ). This

Table 1. Selected Bond Lengths and Angles in 2a-c, 3a,b and $\mathrm{Cp}_{2}(\mathrm{Ge} / \mathrm{Sn} / \mathrm{Pb})^{a}$

$\begin{array}{lllll} & \text { E-Cp }[\mathrm{pm}] & \alpha^{b}[\mathrm{deg}] & \beta^{c}[\mathrm{deg}] & \gamma^{d}[\mathrm{deg}] \\ \mathrm{Cp}_{2} \mathrm{Ge} & 223.4 & 50.2 & 156.9-157.4 & \\ \mathrm{Cp}_{2} \mathrm{Sn} & 237.0-243.7 & 45.9-46.7 & 146.9-147.4 & \\ \mathrm{Cp}_{2} \mathrm{~Pb} & 244.1-252.7 & 53.6 & 131.0-134.6 & \\ \mathbf{2 a} & 222.1-225.3 & 44.9 & 157.1 & 143.9 \\ \mathbf{2 b} & 239.2-241.6 & 49.8 & 147.7 & 144.5 \\ \text { 2c } & 243.0-256.0 & 36.3-54.2 & 137.1-151.5 & 143.7-149.8 \\ \text { 3a } & 257.0 & 37.6 & 140.9 & 148.0 \\ \text { 3b } & 260.5 & 37.0 & 140.5 & 150.8\end{array}$

${ }^{a}$ Range values given because multiple molecules are found in the asymmetric unit and/or the bond is found more than once in the molecule. ${ }^{b}$ Dihedral angle of $\mathrm{Cp}$ planes ${ }^{c} \mathrm{Cp}^{\text {centroid }}-\mathrm{E}-\mathrm{Cp}^{\text {centroid }}$ angle ${ }^{d} \mathrm{Si}-\mathrm{O}-\mathrm{Si}$ angle.

is because of the fact that the $\mathrm{Si}-\mathrm{O}-\mathrm{Si}$ moiety is very flexible and that the ansa-bridge is not bound to be positioned on the far side relative to the lone pair of the central atom (Chart 1, 2I), but can be located laterally (Chart 1, 2-II). This is more pronounced in germanocenophane, $\mathbf{2 a}$, with shorter $\mathrm{Ge}-\mathrm{Cp}$ bonds and a larger dihedral angle $\alpha$ between the Cp planes, and less pronounced in stannocenophane, $2 \mathrm{~b}\left(2 \mathrm{a}: \phi^{32}=56.1^{\circ}\right.$; 2b: $\left.\phi^{32}=51.1^{\circ}\right)$, and indicates that the lone pair has a stronger effect on the dihedral angle $\alpha$ than the ansa-bridge in tetrelocenophanes $\mathbf{2 a}-\mathbf{c}$. In all cases, however, packing effects in the crystal have to be taken into consideration as well.
Chart 1. Illustration of Different Orientations of the ansaBridge Relative to the Lone Pair at the Central Atom in Disiloxa[3] tetrelocenophanes 2

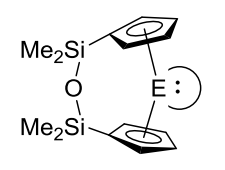

2-I

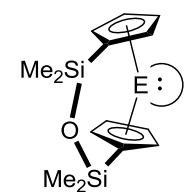

2-II
As tetrelocenophanes $\mathbf{2 a - c}$ could be of interest as monomers in the preparation of the corresponding polymetallocenylsiloxanes, we explored the possibility to prepare an analogous disiloxanyl-bridged distannocene, which would be a two-repeat-unit model compound of such a polymer. This is in analogy to a report of Zuckerman and co-workers on the synthesis of a xylyl-bridged distannocene. ${ }^{6}$ However, when dilithiated ligand, $\mathbf{1}$, was reacted with two equivalents of cyclopentadienyltin(II) chloride, the ${ }^{1} \mathrm{H},{ }^{13} \mathrm{C}$, and ${ }^{119} \mathrm{Sn}$ NMR spectra showed exclusive formation of stannocenophane, $\mathbf{2 b}$, and stannocene, $4\left[\delta^{119} \mathrm{Sn}=-2124\right.$ (2b), -2199 (4) (Scheme 2). It remains unclear, whether a bridged

Scheme 2. Reaction of Dilithiated Ligand, 1, with Cyclopentadienyltin(II) Chloride, To Give Stannocenophane, $2 \mathrm{~b}$, and Stannocene, 4

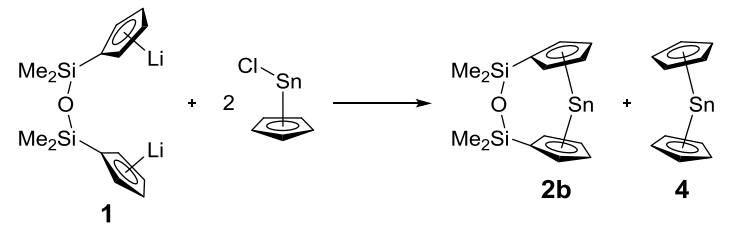

distannocene is initially formed and undergoes a subsequent redistribution reaction to give $\mathbf{2 b}$ and $\mathbf{4}$, or if cyclopentadienyllithium is eliminated from a monosubstituted intermediate, giving $\mathbf{2 b}$ and reacting with cyclopentadienyltin(II) chloride to give 4 . In either case, entropic effect might be the driving force for the formation of $2 b$ and 4 as the sole products of the reaction.

In light of these results, it remains unclear if Zuckerman and co-workers had actually obtained a xylyl-bridged distannocene, as no ${ }^{119} \mathrm{Sn}$ NMR chemical shifts or structural characterization were reported. ${ }^{6}$

Polymetallocenes are most commonly prepared by ringopening polymerizations starting from the corresponding metallocenophanes, by cleavage of either the metal-Cp bond or the ansa-bridge-Cp bond. ${ }^{2}$ Because previous studies of stannocene carbene complexes revealed that the coordination of a strong $\sigma$ donor can weaken the metal-Cp bond, ${ }^{33}$ this was further explored as a potential mechanism for metal-Cp bond activation in tetrelocenophanes, by reacting stannocenophane, 2b, with 1,3,4,5-tetramethyl-imidazole-2-ylidene. Upon mixing stannocenophane $\mathbf{2 b}$ and NHC in benzene at room temperature and examining the mixture by multinuclear NMR spectroscopy, a downfield shift of the ${ }^{119} \mathrm{Sn}$ resonance was observed $\left(\delta^{119} \mathrm{Sn}=-1761 ; \Delta \delta^{119} \mathrm{Sn}=363\right.$ vs $\left.2 \mathbf{b}\right)$, along with a resonance of $\delta^{13} \mathrm{C}=200.3$ for the carbene carbon atom. These findings clearly indicate a coordination of $\mathrm{NHC}$ to the tin atom in stannocenophane $\mathbf{2 b}$. Likewise, when plumbocenophane $\mathbf{2 c}$ was reacted with 1,3,4,5-tetramethyl-imidazole-2-ylidene in 
toluene at room temperature, a similar coordination was observed (Scheme 3). ${ }^{34}$

Scheme 3. Reaction of Disiloxa[3]tetrelocenophanes, $2 b, c$, with NHC To Give NHC Complexes 3a,b (2b/3a: E = Sn; 2c/3b: $\mathrm{E}=\mathrm{Pb} ; \mathrm{NHC}=1,3,4,5$-Tetramethyl-imidazole-2ylidene)

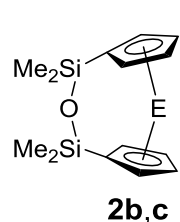

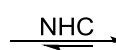

2b,c

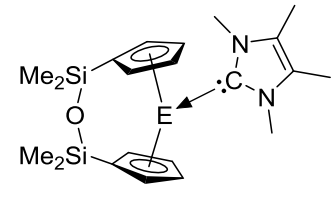

$3 a, b$
Crystals of complexes 3a,b suitable for single crystal X-ray diffraction analysis, could be obtained from thf (3a) and toluene (3b) solutions at $248 \mathrm{~K}$, allowing for structural characterization (Figure 2). Noteworthy, plumbocenophane
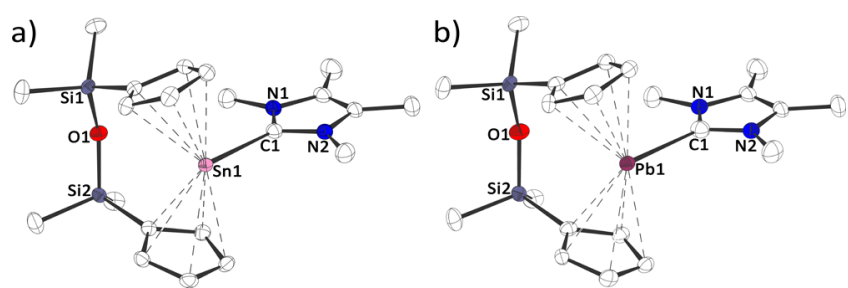

Figure 2. Molecular structure of (a) stannocenophane NHC complex $\mathbf{3 a}$ and (b) plumbocenophane NHC complex $\mathbf{3 b}$ in the crystal (thermal ellipsoids at $50 \%$ probability level, $\mathrm{H}$ atoms omitted for clarity).

NHC complex $\mathbf{3 b}$ represents the first example of a carbene adduct of a bis(cyclopentadienyl)lead compound. The $\mathrm{Sn}-$ $\mathrm{C}^{\mathrm{NHC}}$ bond in complex $3 \mathrm{a}$ is $245.7 \mathrm{pm}$, the $\mathrm{Pb}-\mathrm{C}^{\mathrm{NHC}}$ bond in complex $3 \mathbf{b}$ is $258.2 \mathrm{pm}$. This is comparably long (e.g.,: $\left\{\left(\mathrm{Me}_{3} \mathrm{Si}\right)_{3} \mathrm{Si}\right\}_{2} \mathrm{~S} \mathrm{n}-\mathrm{NHC}: 228.7 \mathrm{pm} ;{ }^{35}$ $\left\{\left(\mathrm{Me}_{2} \mathrm{Si}\right)_{2}\left(\left(\mathrm{Me}_{3} \mathrm{Si}\right)_{2} \mathrm{Si}\right)_{2}\right\} \mathrm{Sn}-\mathrm{NHC}: 229.5 \mathrm{pm} ;{ }^{35} \mathrm{Ter}(\mathrm{H}) \mathrm{Pb}-$ NHC: $\left.233.2 \mathrm{pm}^{36}\right)$, but similar to what has been observed previously for stannocene carbene complexes. ${ }^{33}$ The E-Cp bonds in complexes $\mathbf{3} \mathbf{a}, \mathbf{b}$ are significantly elongated compared to stannocenophane $\mathbf{2 b}$ and plumbocenophane $\mathbf{2 c}$, respectively (Table 1), which indicates a weakening of the metal Cp bonds upon coordination of NHC. This is in line with the previous observations in stannocene carbene complexes ${ }^{33}$ and can be rationalized by the donation of the carbene into the antibonding lowest unoccupied molecular orbital (LUMO) of the metallocene (Figure 3).

The LUMO of stannocenophane $\mathbf{2 b}$ and plumbocenophane $2 c$, as is typical for tetrelocenes in general, corresponds to an antibonding interaction of a p-orbital at the central atom with the cyclopentadienyl ligand orbitals. ${ }^{12,13,33}$ Therefore, the NHC coordinates to the metal atom in $\mathbf{3 a}, \mathbf{b}$. In a "side-on" fashion and donation of electron density into the LUMO weakens the $\mathrm{E}-\mathrm{Cp}$ bond. This is further illustrated by the fact that complex $3 \mathbf{a}$ is extremely reactive and decomposes in solution at room temperature within hours. The fact that only a weakening and no cleavage of the $\mathrm{E}-\mathrm{Cp}$ bonds is observed, might be due to the fact that the carbene coordination is relatively weak. This is in line with calculated complexation energies of $\Delta E=-65.9 \mathrm{~kJ} \mathrm{~mol}^{-1}\left(\Delta G^{298}=-5.3 \mathrm{~kJ} \mathrm{~mol}^{-1}\right)$ for 3a and $\Delta E=-72.2 \mathrm{~kJ} \mathrm{~mol}^{-1}\left(\Delta G^{298}=-17.9 \mathrm{~kJ} \mathrm{~mol}^{-1}\right)$ for $3 \mathbf{b}$

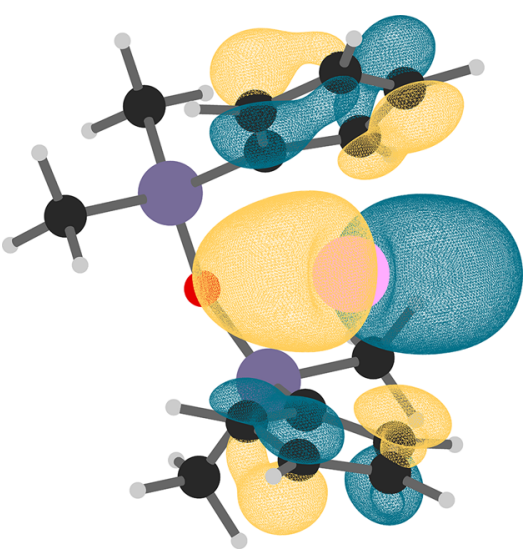

Figure 3. Isosurface plot of the LUMO (Kohn-Sham orbital) of stannocenophane 2b (B3LYP-D3/def2-TZVP, isovalue $=0.035)$.

(complexation energies refer to the reactions $\mathbf{3 a}, \mathbf{b} \rightarrow \mathbf{2 b}, \mathbf{c}+$ $\mathrm{NHC}$ and are calculated at B3LYP-D3/def2-TZVP ${ }^{37}$ ). Therefore, $\mathbf{3 a}, \mathbf{b}$ might exist in a dissociative equilibrium in solution and an averaged set of signals is observed in the NMR spectra at room temperature.

To probe this further, solid state ${ }^{13} \mathrm{C}$ and ${ }^{119} \mathrm{Sn} \mathrm{CP} / \mathrm{MAS}$ NMR measurements of complex 3a were conducted (Figure 4). Stannocenophane NHC complex 3a exhibits a ${ }^{119} \mathrm{Sn}$ NMR

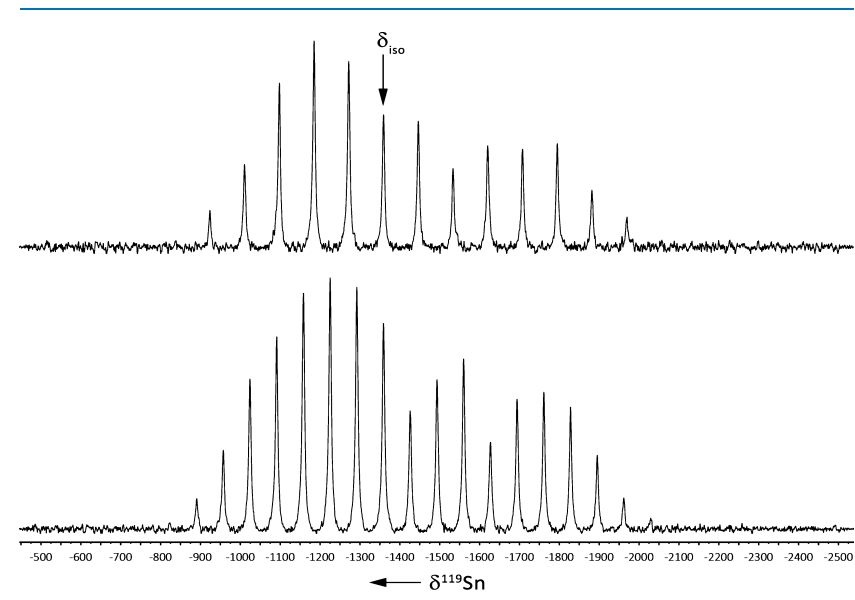

Figure 4. ${ }^{119} \mathrm{Sn}\left\{{ }^{1} \mathrm{H}\right\}$ CP/MAS NMR spectra of stannocenophane NHC complex 3a. Upper trace: $13 \mathrm{kHz}$ MAS, lower trace: $10 \mathrm{kHz}$ MAS $\left[\delta_{\text {iso }}=-1360 ; \delta_{11}=-907( \pm 7) ; \delta_{22}=-1210( \pm 6) ; \delta_{33}=\right.$ $\left.-1962( \pm 1) ; \Omega\left(\delta_{11}-\delta_{33}\right)=1055\right]$.

chemical shift in the solid state of $\delta^{119} \mathrm{Sn}=-1360$, which is downfield shifted by $\Delta \delta^{119} \mathrm{Sn}=401$ compared to what is observed in solution at room temperature. The carbene-carbon atom exhibits a ${ }^{13} \mathrm{C}$ NMR chemical shift of $\delta^{13} \mathrm{C}=196.5$ in the solid state, with a C-Sn coupling constant of ${ }^{1} J_{\mathrm{CSn}}=587 \mathrm{~Hz}$. This clearly indicates that an averaged set of signals is observed in solution at room temperature and that stannocenophane NHC complex $3 a$ in fact exists in a dissociative equilibrium with stannocenophane $\mathbf{2 b}+$ NHC.

To further verify this, the stoichiometry of the reaction was varied. When two equivalents of stannocenophane, $\mathbf{2} \mathbf{b}$, are mixed with one equivalent of NHC, only one set of signals is observed in the ${ }^{1} \mathrm{H}$ and ${ }^{13} \mathrm{C}$ NMR spectra, along with one signal in the ${ }^{119} \mathrm{Sn}$ NMR spectra at $\delta^{119} \mathrm{Sn}=-1976$. This is upfield shifted by $\Delta \delta^{119} \mathrm{Sn}=215$, compared to what was observed for solutions derived from $3 a{ }^{2}\left(\delta^{119} \mathrm{Sn}=-1761\right)$, 
indicating a fast equilibrium between carbene complex, 3a, and uncoordinated $\mathbf{2} \mathbf{b}+\mathrm{NHC}^{38}$ In addition, when a solution of $\mathbf{3 a}$ or $\mathbf{3 b}$ is treated with aluminum chloride, almost instantaneous formation of $\mathrm{NHC} \cdot \mathrm{AlCl}_{3}$ and metallocenophanes $\mathbf{2 b , c}$ is observed by multinuclear NMR spectroscopy (Scheme 4). ${ }^{39}$

Scheme 4. Reaction of NHC Complexes 3a,b with $\mathrm{AlCl}_{3}$ (2b/3a: E = Sn; 2c/3b: E = Pb; NHC = 1,3,4,5-Tetramethylimidazole-2-ylidene)
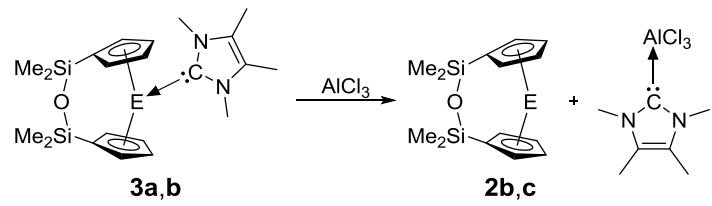

This further supports the assumption that the NHC coordination is reversible and that $\mathbf{3 a} \mathbf{a}, \mathbf{b}$ exist in a dissociative equilibrium with $\mathbf{2 b}, \mathbf{c}+\mathrm{NHC}$.

\section{CONCLUSIONS}

In summary, the synthesis and structural characterization of tetramethyldisiloxa[3]germanocenophane, 2a, tetramethyldisiloxa[3] stannocenophane, $\mathbf{2 b}$, and tetramethyldisiloxa[3]plumbocenophane, $2 \mathrm{c}$ is reported. In case of stannocenophane, $\mathbf{2 b}$, it was shown that it can also be obtained by treatment of dilithiated ligand $\mathbf{1}$, with two equivalents of cyclopentadienyltin(II) chloride, which might reveal Zuckerman's report of a distannocene in a different light. Furthermore, stannocenophane $\mathbf{2 b}$, and plumbocenophane $2 \mathrm{c}$ react with 1,3,4,5-tetramethyl-imidazole-2-ylidene (NHC) to give the corresponding carbene complexes $\mathbf{3 a}, \mathbf{b}$. These complexes are believed to exist in a dissociative equilibrium in solution at room temperature, as indicated by comparison of solution and solid state $\mathrm{CP} / \mathrm{MAS}{ }^{119} \mathrm{Sn}$ NMR spectroscopy in case of 3a, as well as abstraction of NHC by treatment of $\mathbf{3 a , b}$ with aluminum chloride and calculated complexation energies $(\Delta E)$ of just $-65.9 \mathrm{~kJ} \mathrm{~mol}^{-1}(3 \mathbf{a})$ and $-72.2 \mathrm{~kJ} \mathrm{~mol}^{-1}(3 \mathbf{b})$.

\section{EXPERIMENTAL SECTION}

All manipulations were carried out under an inert gas atmosphere (argon 5.0), using either Schlenk line techniques of a glovebox. Dilithiated ligand $1,^{21-24,26} 1,3,4,5$-tetramethylimidazole-2-ylidene, ${ }^{40}$ and cyclopentadienyltin(II) chloride $^{41-43}$ were synthesized according to literature-known procedures. NMR-spectra were recorded on Bruker AVANCE III 300 (solution NMR), Bruker AVANCE III 400 (solution NMR), and Bruker Ascend 400WB (solid state NMR) spectrometers. ${ }^{1} \mathrm{H}$ and ${ }^{13} \mathrm{C}$ NMR spectra were referenced using the solvent signals $\left[\delta^{1} \mathrm{H}\left(\mathrm{C}_{6} \mathrm{HD}_{5}\right)=7.16 ; \delta^{13} \mathrm{C}\left(\mathrm{C}_{6} \mathrm{D}_{6}\right)=\right.$ 128.06]. ${ }^{29} \mathrm{Si},{ }^{119} \mathrm{Sn}$, and ${ }^{207} \mathrm{~Pb}$ NMR spectra were referenced using external standards $\left[\delta^{29} \mathrm{Si}\left(\mathrm{SiMe}_{4}\right)=0 ; \delta^{119} \mathrm{Sn}\left(\mathrm{SnMe}_{4}\right)=\right.$ $0 ; \delta^{207} \mathrm{~Pb}\left(\mathrm{PbMe}_{4}\right)=0$ ]. Elemental analysis were performed on an Elementar vario MICRO cube (in some cases low carbon values were repeatedly reproducibly observed, presumably because of the formation of silicon carbide). Single crystal Xray diffraction analysis was carried out at low temperatures on Bruker AXS X8 Apex CCD and Bruker AXS D8 Venture diffractometers operating with graphite monochromated Mo $\mathrm{K} \alpha$ radiation. Structure solution and refinement were performed using SHELX. ${ }^{44}$ Crystal structures have been deposited with the Cambridge Crystallographic Data Centre
(CCDC) and are available free of charge from the Cambridge Structural Database (reference numbers: 1903471, 1903472, 1903473, 1903474, 1941170).

Synthesis of $2 \mathrm{a}-\mathrm{c}$. Dilithiated ligand 1 (500 mg, 1.82 $\mathrm{mmol})$ and the respective element dichloride $\left(\mathrm{GeCl}_{2} 1,4-\right.$ dioxane: $421 \mathrm{mg}, 1.82 \mathrm{mmol} ; \mathrm{SnCl}_{2}: 346 \mathrm{mg}, 1.82 \mathrm{mmol}$; $\mathrm{PbCl}_{2}: 507 \mathrm{mg}, 1.82 \mathrm{mmol}$ ) were added to a Schlenk flask and cooled to $173 \mathrm{~K}$. Precooled thf was added and the solution was stirred at $173 \mathrm{~K}$ for $90 \mathrm{~min}$. Subsequently, the mixture was allowed to warm to room temperature and stirred for an additional $150 \mathrm{~min}$. All volatiles were removed in vacuo and the residue was suspended in hexane. After filtration, the solution was concentrated and stored at $248 \mathrm{~K}$ to obtain $2 \mathrm{a}-\mathrm{c}$ as crystalline solids.

Yields: 2a: $500 \mathrm{mg} / 82 \%$; 2b: $490 \mathrm{mg} / 70 \%$; 2c: $460 \mathrm{mg} /$ $54 \%$.

2a: ${ }^{1} \mathrm{H}$ NMR $\left(400.13 \mathrm{MHz}, 296 \mathrm{~K}, \mathrm{C}_{6} \mathrm{D}_{6}\right): \delta 0.35(\mathrm{~s}, 12 \mathrm{H}$, $\left.\mathrm{Si}-\mathrm{CH}_{3}\right), 6.02\left(\mathrm{t},{ }^{3} \mathrm{~J}_{\mathrm{HH}}=2 \mathrm{~Hz}, 4 \mathrm{H}, \mathrm{Cp}\right), 6.28\left(\mathrm{t},{ }^{3} J_{\mathrm{HH}}=2 \mathrm{~Hz}\right.$, $4 \mathrm{H}, \mathrm{Cp}) ;{ }^{13} \mathrm{C}\left\{{ }^{1} \mathrm{H}\right\}$ NMR $\left(100.62 \mathrm{MHz}, 296 \mathrm{~K}, \mathrm{C}_{6} \mathrm{D}_{6}\right): \delta 1.6$ $\left(\mathrm{Si}-\mathrm{CH}_{3}\right), 113.7(\mathrm{Cp}), 118.3(\mathrm{Cp}), 121.7(\mathrm{Cp}) ;{ }^{29} \mathrm{Si}\left\{{ }^{1} \mathrm{H}\right\}$ INEPT NMR (79.49 MHz, $\left.296 \mathrm{~K}, \mathrm{C}_{6} \mathrm{D}_{6}\right): \delta-4.5$. Elemental analysis for $\mathrm{C}_{14} \mathrm{H}_{20} \mathrm{GeOSi}_{2}$ : Calcd: $50.48 \%, \mathrm{C}$; $6.05 \%, \mathrm{H}$. Found: $49.41 \%, \mathrm{C} ; 6.11 \%, \mathrm{H}$.

2b: ${ }^{1} \mathrm{H}$ NMR (400.13 MHz, $\left.297 \mathrm{~K}, \mathrm{C}_{6} \mathrm{D}_{6}\right): \delta 0.37(\mathrm{~s}, 12 \mathrm{H}$, $\left.\mathrm{Si}-\mathrm{CH}_{3}\right), 6.06\left(\mathrm{t},{ }^{3} \mathrm{~J}_{\mathrm{HH}}=2 \mathrm{~Hz},{ }^{2} J_{\mathrm{HSn}}=20 \mathrm{~Hz}, 4 \mathrm{H}, \mathrm{Cp}\right), 6.25(\mathrm{t}$, $\left.{ }^{3} J_{\mathrm{HH}}=2 \mathrm{~Hz}, 4 \mathrm{H}, \mathrm{Cp}\right) ;{ }^{13} \mathrm{C}\left\{{ }^{1} \mathrm{H}\right\} \mathrm{NMR}(100.62 \mathrm{MHz}, 297 \mathrm{~K}$, $\left.\mathrm{C}_{6} \mathrm{D}_{6}\right): \delta 1.8\left(\mathrm{Si}-\underline{\mathrm{CH}}_{3}\right), 115.2(\mathrm{Cp}), 116.9(\mathrm{Cp}), 118.2(\mathrm{Cp}$, $\left.{ }^{1} J_{\mathrm{CSn}}=49.5 \mathrm{~Hz}, 51.7 \mathrm{~Hz}\right) ;{ }^{29} \mathrm{Si}\left\{{ }^{1} \mathrm{H}\right\}$ INEPT NMR $(79.49$ $\left.\mathrm{MHz}, 297 \mathrm{~K}, \mathrm{C}_{6} \mathrm{D}_{6}\right): \delta-5.6 ;{ }^{119} \mathrm{Sn}\left\{{ }^{1} \mathrm{H}\right\} \operatorname{NMR}(148.89 \mathrm{MHz}$, $\left.297 \mathrm{~K}, \mathrm{C}_{6} \mathrm{D}_{6}\right): \delta-2124$. Elemental analysis for $\mathrm{C}_{14} \mathrm{H}_{20} \mathrm{OSi}_{2} \mathrm{Sn}$ : Calcd: $44.35 \%$, C; $5.32 \%$, H. Found: $43.75 \%$, C; 5.34\%, H.

2c: ${ }^{1} \mathrm{H}$ NMR $\left(300.13 \mathrm{MHz}, 299 \mathrm{~K}, \mathrm{C}_{6} \mathrm{D}_{6}\right): \delta 0.41(\mathrm{~s}, 12 \mathrm{H}$, $\left.\mathrm{Si}-\mathrm{CH}_{3}\right), 6.04(\mathrm{~m}, 4 \mathrm{H}, \mathrm{Cp}), 6.24(\mathrm{~m}, 4 \mathrm{H}, \mathrm{Cp}) ;{ }^{13} \mathrm{C}\left\{{ }^{1} \mathrm{H}\right\}$ NMR (75.48 MHz, $\left.299 \mathrm{~K}, \mathrm{C}_{6} \mathrm{D}_{6}\right): \delta 1.9\left(\mathrm{Si}-\underline{\mathrm{CH}}_{3}\right), 116.8$ (Cp), 117.7 (Cp), 118.9 (Cp); ${ }^{29} \mathrm{Si}\left\{{ }^{1} \mathrm{H}\right\}$ NMR (59.63 MHz, $\left.299 \mathrm{~K}, \mathrm{C}_{6} \mathrm{D}_{6}\right): \delta-7.1 ;{ }^{207} \mathrm{~Pb}\left\{{ }^{1} \mathrm{H}\right\} \operatorname{NMR}(62.51 \mathrm{MHz}, 299 \mathrm{~K}$, $\left.\mathrm{C}_{6} \mathrm{D}_{6}\right): \delta-4795$. Elemental analysis for $\mathrm{C}_{14} \mathrm{H}_{20} \mathrm{OPbSi}_{2}$ : Calcd: $35.95 \%, \mathrm{C} ; 4.31 \%$, H. Found: $36.4 \%$, C; $4.93 \%, \mathrm{H}$.

Synthesis of 3 a. Stannocenophane 2 b $(50.0 \mathrm{mg}, 132$ $\mu \mathrm{mol})$ and 1,3,4,5-tetramethyl-imidazole-2-ylidene $(16.0 \mathrm{mg}$, $129 \mu \mathrm{mol}$ ) were mixed, $2 \mathrm{~mL}$ of thf, precooled to $193 \mathrm{~K}$, were added, and the resulting mixture was stirred for $10 \mathrm{~min}$ at 193 $\mathrm{K}$. Storage of the solution at $248 \mathrm{~K}$ yielded yellow crystals of stannocenophane carbene complex $3 \mathbf{a}$.

Yield: $10 \mathrm{mg} / 17 \% .{ }^{1} \mathrm{H}$ NMR (400.13 MHz, $\left.296 \mathrm{~K}, \mathrm{C}_{6} \mathrm{D}_{6}\right): \delta$ $0.54\left(\mathrm{~s}, 12 \mathrm{H}, \mathrm{Si}-\mathrm{CH}_{3}\right), 1.34\left(\mathrm{~s}, 6 \mathrm{H}, \mathrm{C}-\mathrm{CH}_{3}\right), 3.13(\mathrm{~s}, 6 \mathrm{H}, \mathrm{N}-$ $\left.\mathrm{CH}_{3}\right), 6.30-6.36(\mathrm{~m}, 8 \mathrm{H}, \mathrm{Cp}) ;{ }^{13} \mathrm{C}\left\{{ }^{1} \mathrm{H}\right\}$ NMR (100.62 MHz, $\left.296 \mathrm{~K}, \mathrm{C}_{6} \mathrm{D}_{6}\right): \delta 2.3\left(\mathrm{Si}-\mathrm{CH}_{3}\right), 8.1\left(\mathrm{C}-\underline{\mathrm{CH}}_{3}\right), 33.6\left(\mathrm{~N}-\mathrm{CH}_{3}\right)$, $115.9(\mathrm{Cp}), 116.7(\mathrm{Cp}), 123.3\left(\mathrm{C}-\mathrm{CH}_{3}\right), 200.3$ [carbene-C (detected by $\left.\left.{ }^{1} \mathrm{H}-{ }^{13} \mathrm{C}-\mathrm{HMBC}\right)\right] ;{ }^{13} \mathrm{C}\left\{{ }^{1} \mathrm{H}\right\} \mathrm{CP} / \mathrm{MAS}(13 \mathrm{kHz})$ NMR (100.67 MHz, $295 \mathrm{~K}): \delta 2.6\left(\mathrm{Si}-\underline{\mathrm{CH}}_{3}\right), 3.3\left(\mathrm{Si}-\underline{\mathrm{CH}}_{3}\right)$, $7.6\left(\underline{\mathrm{CH}}_{3}\right), 10.2\left(\underline{\mathrm{CH}}_{3}\right), 34.2\left(\underline{\mathrm{CH}}_{3}\right), 111.3,112.9,117.8$, $120.1,123.2,125.3,196.5$ (carbene-C, ${ }^{1} J_{\mathrm{CSn}}=587 \mathrm{~Hz}$ ); ${ }^{29} \mathrm{Si}\left\{{ }^{1} \mathrm{H}\right\} \mathrm{NMR}\left(79.49 \mathrm{MHz}, 296 \mathrm{~K}, \mathrm{C}_{6} \mathrm{D}_{6}\right): \delta-5.7 ;{ }^{119} \mathrm{Sn}\left\{{ }^{1} \mathrm{H}\right\}$ NMR $\left(111.68 \mathrm{MHz}, 299 \mathrm{~K}, \mathrm{C}_{6} \mathrm{D}_{6}\right): \delta-1761 ;{ }^{119} \mathrm{Sn}\left\{{ }^{1} \mathrm{H}\right\} \mathrm{CP} /$ MAS $(13 \mathrm{kHz})$ NMR $(149.05 \mathrm{MHz}, 295 \mathrm{~K}): \delta_{\text {iso }}-1360$. Elemental analysis for $\mathrm{C}_{21} \mathrm{H}_{32} \mathrm{~N}_{2} \mathrm{OSi}_{2} \mathrm{Sn}$ : Calcd: C, $50.11 \%$; $\mathrm{H}$, $6.41 \%$; N, 5.57\%. Found: C, 50.11\%; H, 6.40\%; N, 5.72\%.

Synthesis of $3 \mathbf{b}$. A solution of Plumbocenophane $2 \mathrm{c}(80.0$ $\mathrm{mg}, 171 \mu \mathrm{mol})$ in $3 \mathrm{~mL}$ of toluene was added to a solution of 1,3,4,5-tetramethyl-imidazole-2-ylidene $(21.0 \mathrm{mg}, 169 \mu \mathrm{mol})$ in $3 \mathrm{~mL}$ of toluene and the mixture was stirred for $5 \mathrm{~min}$. 
Storage of the solution at $248 \mathrm{~K}$ yielded large yellow crystals of plumbocenophane carbene complex $\mathbf{3 b}$.

Yield: $38 \mathrm{mg} / 38 \% .{ }^{1} \mathrm{H}$ NMR (400.13 MHz, $\left.293 \mathrm{~K}, \mathrm{C}_{6} \mathrm{D}_{6}\right): \delta$ $0.64\left(\mathrm{~s}, 12 \mathrm{H}, \mathrm{Si}-\mathrm{CH}_{3}\right), 1.32\left(\mathrm{~s}, 6 \mathrm{H}, \mathrm{C}-\mathrm{CH}_{3}\right), 3.04(\mathrm{~s}, 6 \mathrm{H}, \mathrm{N}-$ $\left.\mathrm{CH}_{3}\right), 6.34(\mathrm{~m}, 4 \mathrm{H}, \mathrm{Cp}), 6.39(\mathrm{~m}, 4 \mathrm{H}, \mathrm{Cp}) ;{ }^{13} \mathrm{C}\left\{{ }^{1} \mathrm{H}\right\} \mathrm{NMR}$ $\left(100.63 \mathrm{MHz}, 293 \mathrm{~K}, \mathrm{C}_{6} \mathrm{D}_{6}\right): \delta 2.4\left(\mathrm{Si}-\underline{\mathrm{CH}}_{3}\right), 8.2\left(\mathrm{C}-\underline{\mathrm{CH}}_{3}\right)$, $34.3\left(\mathrm{~N}-\mathrm{CH}_{3}\right), 114.4(\mathrm{Cp}), 117.0(\mathrm{Cp}), 119.2(\mathrm{Cp}), 123.7$ $\left(\mathrm{C}-\mathrm{CH}_{3}\right) ;{ }^{29} \mathrm{Si}\left\{{ }^{1} \mathrm{H}\right\}$ INEPT NMR $(79.49 \mathrm{MHz}, 293 \mathrm{~K}$, $\left.\mathrm{C}_{6} \mathrm{D}_{6}\right): \delta-7.0 ;{ }^{207} \mathrm{~Pb} \operatorname{NMR}\left(62.51 \mathrm{MHz}, 295 \mathrm{~K}, \mathrm{C}_{6} \mathrm{D}_{6}\right)$ : no signal could be detected in the ${ }^{207} \mathrm{~Pb}$ NMR spectrum in a range of -2000 to $-6800 \mathrm{ppm}$.

Elemental analysis for $\mathrm{C}_{21} \mathrm{H}_{32} \mathrm{~N}_{2} \mathrm{OPbSi}_{2}$ : Calcd: C, 42.62\%; H, 5.45\%; N, 4.73\%. Found: C, 43.06\%; H, 5.59\%; N, $4.40 \%$.

\section{ASSOCIATED CONTENT}

\section{S Supporting Information}

The Supporting Information is available free of charge on the ACS Publications website at DOI: 10.1021/acsomega.9b02605.

NMR spectra, computational details, and references (PDF) Optimized geometries (XYZ) Crystallographic details of $2 \mathrm{a}$ (CIF) Crystallographic details of $2 b$ (CIF) Crystallographic details of $2 c$ (CIF) Crystallographic details of $3 \mathrm{a}$ (CIF) Crystallographic details of $3 b$ (CIF)

\section{AUTHOR INFORMATION}

\section{Corresponding Author}

*E-mail: andre.schaefer@uni-saarland.de.

\section{ORCID}

André Schäfer: 0000-0002-5969-6618

\section{Notes}

The authors declare no competing financial interest.

\section{ACKNOWLEDGMENTS}

Prof. Dr. Guido Kickelbick is thanked for his support. Susanne Harling is thanked for performing elemental analysis. Funding of this research by the Deutsche Forschungsgemeinschaft (DFG, German Research Foundation, SCHA 1915/3-1) and Fonds der Chemischen Industrie (FCI) is gratefully acknowledged. We acknowledge support by the Deutsche Forschungsgemeinschaft (DFG, German Research Foundation) and Saarland University within the funding program Open Access Publishing.

\section{REFERENCES}

(1) Herbert, D. E.; Mayer, U. F. J.; Manners, I. Strained Metallocenophanes and Related Organometallic Rings Containing $\pi$-Hydrocarbon Ligands and Transition-Metal Centers. Angew. Chem. Int. Ed 2007, 46, 5060-5081; Angew. Chem. 2007, 119, 5152-5173.

(2) Wang, B. Ansa-metallocene polymerization catalysts: Effects of the bridges on the catalytic activities. Coord. Chem. Rev. 2006, 250, 242-258.

(3) Hailes, R. L. N.; Oliver, A. M.; Gwyther, J.; Whittell, G. R.; Manners, I. Polyferrocenylsilanes: synthesis, properties, and applications. Chem. Soc. Rev. 2016, 45, 5358-5407.

(4) Jutzi, P.; Krallmann, R.; Wolf, G.; Neumann, B.; Stammler, H.-G. Synthese von $6,6,7,7,13,13,14,14$-Octamethyl-6,7,13,14-tetrasiladispiro[4.2.4.2]-tetradeca-1,3,9,11-tetraen und sein Einsatz in der $\pi$ Komplexchemie von p- und d-Block-Elementen. Chem. Ber. 1991, 124, 2391-2399.
(5) Jutzi, P.; Dickbreder, R. Metallkomplexe mit verbrückten permethylierten Cyclopentadienylliganden. Chem. Ber. 1986, 119, $1750-1754$.

(6) Dory, T. S.; Zuckerman, J. J. Stannocenophanes. Ring-bridged di- $\eta^{5}$-cyclopentadienyltin(II) derivatives of $\alpha, \alpha$-dicyclopentadienylortho-, -meta- and -para-xylene. J. Organomet. Chem. 1984, 264, 295303.

(7) Tacke, M. Direct Synthesis of ansa-Metallocenes of Tin and Lead via Metal Vapor Cocondensation. Organometallics 1994, 13, 4124-4125.

(8) Pitotti, C. J.; Roth, E. P.; Canfield, G. M.; Johnson, J. E. B.; Balaich, G. J.; Zakharov, L. N.; Rheingold, A. L. A New $\mathrm{C}_{2}$-Symmetric Ligand for ansa-Metallocene Chemistry: Synthesis and X-ray Crystal Structure of the ansa-Stannocene Complex rac$\left[\left(\mathrm{CHBu}^{\mathrm{t}}\right)_{2}\left(\mathrm{C}_{5} \mathrm{H}_{2} \mathrm{Bu}_{2}^{\mathrm{t}}\right)_{2}\right]$ Sn. Organometallics 2005, 24, 1806-1808.

(9) Stahlich, A. S. D.; Huch, V.; Grandjean, A.; Rohe, K.; Leszczyńska, K. I.; Scheschkewitz, D.; Schäfer, A. Permethylated Disila[2]metallocenophanes of Group 14 and 15 Elements. Chem.Eur. J. 2019, 25, 173-176.

(10) Schäfer, A.; Rohe, K.; Grandjean, A.; Huch, V. Synthesis and Structure of [2]Tetrelocenophanes. Eur. J. Inorg. Chem. 2017, 35-38.

(11) Budzelaar, P. H. M.; Engelberts, J. J.; van Lenthe, J. H. Trends in Cyclopentadienyl-Main-Group-Metal Bonding. Organometallics 2003, 22, 1562-1576.

(12) Jutzi, P.; Burford, N. Structurally Diverse $\pi$-Cyclopentadienyl Complexes of the Main Group Elements. Chem. Rev. 1999, 99, 969990.

(13) Beswick, M. A.; Palmer, J. S.; Wright, D. S. p-Block metallocenes: the other side of the coin. Chem. Soc. Rev. 1998, 27, $225-232$.

(14) Fischer, E. O.; Grubert, H. Über Aromatenkomplexe von Metallen. IV. Dicyclopentadienyl-blei. Z. Anorg. Allg. Chem. 1956, 286, 237-242.

(15) Fischer, E. O.; Grubert, H. Di-cyclopentadienyl-zinn. Z. Naturforsch. B 1956, 11b, 423-424.

(16) Mizuhata, Y.; Sasamori, T.; Tokitoh, N. Stable Heavier Carbene Analogues. Chem. Rev. 2009, 109, 3479-3511.

(17) Frenking, G.; Tonner, R.; Klein, S.; Takagi, N.; Shimizu, T.; Krapp, A.; Pandey, K. K.; Parameswaran, P. New bonding modes of carbon and heavier group 14 atoms $\mathrm{Si}-\mathrm{Pb}$. Chem. Soc. Rev. 2014, 43, $5106-5139$

(18) Hadlington, T. J.; Driess, M.; Jones, C. Low-valent group 14 element hydride chemistry: towards catalysis. Chem. Soc. Rev. 2018, 47, 4176-4197.

(19) Nesterov, V.; Reiter, D.; Bag, P.; Frisch, P.; Holzner, R.; Porzelt, A.; Inoue, S. NHCs in Main Group Chemistry. Chem. Rev. 2018, 118, 9678-9842.

(20) Haider, W.; Huch, V.; Schäfer, A. Lewis base complexes of sila[2] aluminocenophanes. Dalton Trans. 2018, 47, 10425-10428.

(21) Mise, T.; Maeda, M.; Nakajima, T.; Kobayashi, K.; Shimizu, I.; Yamamoto, Y.; Wakatsuki, Y. Preparation and structure of the first ansa-molybdenocene and tungstenocene derivatives. Reaction of $\left[\mathrm{O}\left(\mathrm{SiMe}_{2} \mathrm{C}_{5} \mathrm{H}_{4}\right)_{2}\right] \mathrm{MoH}_{2}$ with methyl methacrylate to probe the olefin attacking site. J. Organomet. Chem. 1994, 473, 155-162.

(22) Gräper, J.; Fischer, R. D.; Paolucci, G. Lanthanocene (Ln = $\mathrm{Pr}^{\mathrm{III}}, \mathrm{Yb}^{\mathrm{III}}$ ) chlorides involving tetramethyldisiloxane-interlinked cyclopentadienyl ligands. J. Organomet. Chem. 1994, 471, 87-95.

(23) Curtis, M. D.; D’Errico, J. J.; Duffy, D. N.; Epstein, P. S.; Bell, L. G. Synthesis of titanocene derivatives of tetramethyldisiloxane and poly(methylsiloxane) and the molecular structure of the disiloxanebridged titanocene dichloride [1,3-bis(.eta.5-cyclopentadienyl)1,1,3,3,-tetramethyldisiloxane]titanium(IV) dichloride. Organometallics 1983, 2, 1808-1814.

(24) Angelakos, C.; Zamble, D. B.; Foucher, D. A.; Lough, A. J.; Manners, I. Synthesis, Structures, and the Redistribution and Skeletal Cleavage Reactions of Siloxane-Bridged Ferrocenophanes. Inorg. Chem. 1994, 33, 1709-1718.

(25) Herberhold, M.; Bärtl, T. Ruthenocenophanes. Z. Naturforsch., B: J. Chem. Sci. 1995, 50, 1692-1698. 
(26) Siemeling, U.; Krallmann, R.; Jutzi, P.; Neumann, B.; Stammler, H.-G. [3] Ferrocenophanes with a tetramethyldisiloxane bridge: Synthesis and molecular structure. Monatsh. Chem. 1994, 125, 579586.

(27) Morrison, C. A.; Wright, D. S.; Layfield, R. A. Interpreting Molecular Crystal Disorder in Plumbocene, $\mathrm{Pb}\left(\mathrm{C}_{5} \mathrm{H}_{5}\right)_{2}$ : Insight from Theory. J. Am. Chem. Soc. 2002, 124, 6775-6780.

(28) Overby, J. S.; Hanusa, T. P.; Young, V. G. Redetermination of the Zigzag Modification of Plumbocene at 173 K. Inorg. Chem. 1998, 37, 163-165.

(29) Beswick, M. A.; Lopez-Casideo, C.; Paver, M. A.; Raithby, P. R.; Russell, C. A.; Steiner, A.; Wright, D. S. Solvent directed aggregation of a metallocene; structures of $\left\{\left[\mathrm{Pb}\left(\eta-\mathrm{C}_{5} \mathrm{H}_{5}\right)_{2}\right]_{3}\right.$ $\left.\mathrm{C}_{6} \mathrm{H}_{5} \mathrm{Me}\right\}_{\infty}$ and $\left[\mathrm{Pb}\left(\eta-\mathrm{C}_{5} \mathrm{H}_{5}\right)_{2}\right]_{6}$. Chem. Commun. 1997, 1, 109-110.

(30) Grenz, M.; Hahn, E.; Du Mont, W.-W.; Pickardt, J.; Pickardt, J.; Grenz, M.; Hahn, E. Novel Structures Containing Germanium(II): Germanocene Dimeric Tricarbonyl(di-tert-butoxygermylene) nickel(0). Angew. Chem. Int. Ed 1984, 23, 61-63; Angew. Chem. 1984, 96, 69-70.

(31) Atwood, J. L.; Hunter, W. E.; Cowley, A. H.; Jones, R. A.; Stewart, C. A. X-Ray crystal structures of bis(cyclopentadienyl)tin and bis(pentamethylcyclopentadienyl)lead. J. Chem. Soc., Chem. Commun. 1981, 17, 925-927.

(32) Dihedral angle between $\mathrm{Cp}^{\text {centroid }}-\mathrm{Si}-\mathrm{Si}-\mathrm{Cp}^{\text {centroid }}$ plane and $\mathrm{Cp}^{\text {centroid }}-\mathrm{E}-\mathrm{Cp}^{\text {centroid }}$ plane.

(33) Müller, C.; Stahlich, A.; Wirtz, L.; Gretsch, C.; Huch, V.; Schäfer, A. Carbene Complexes of Stannocenes. Inorg. Chem. 2018, 57, 8050-8053.

(34) When germanocenophane 2a was treated with 1,3,4,5tetramethyl-imidazole-2-ylidene, a complex mixture of products was observed by ${ }^{1} \mathrm{H}$ and ${ }^{13} \mathrm{C}$ NMR spectroscopy at room temperature. Attempts to isolate a complex similar to $\mathbf{3} \mathbf{a}, \mathbf{b}$ were unsuccessful.

(35) Walewska, M.; Hlina, J.; Gaderbauer, W.; Wagner, H.; Baumgartner, J.; Marschner, C. NHC Adducts of Disilylated Germylenes and Stannylenes and Their Coordination Chemistry with Group 11 Metals. Z. Anorg. Allg. Chem. 2016, 642, 1304-1313.

(36) Scheider, J.; Sindlinger, C. P.; Eichele, K.; Schubert, H.; Wesemann, L. Low-Valent Lead Hydride and Its Extreme Low-Field 1H NMR Chemical Shift. J. Am. Chem. Soc. 2017, 139, 6542-6545.

(37) All DFT calculations were performed using the Gaussian 09 Revision D.01 package of programs. See Supporting Information for further information, optimized geometries and references.

(38) VT-NMR investigations at low temperatures did not reveal any signal in the ${ }^{119} \mathrm{Sn}$ NMR spectra, presumably due to low solubility of 3a and extreme signal broadening. Signals in the ${ }^{1} \mathrm{H}$ NMR spectra were slightly shifted, but remained as a single set of signals down to $233 \mathrm{~K}$, indicating a fast equilibrium with low barriers.

(39) $3 \mathbf{a}, \mathbf{b}$ and $\mathrm{AlCl}_{3}$ were mixed and dissolved in $\mathrm{C}_{6} \mathrm{D}_{6}$ and the solution was examined by multinuclear NMR spectroscopy, revealing formation of $\mathbf{2} \mathbf{b}, \mathbf{c}$ along with $\mathrm{NHC} \mathrm{AlCl}_{3}$ and $\left[\mathrm{NHC}_{2} \mathrm{AlCl}_{2}\right]\left[\mathrm{AlCl}_{4}\right]$ (indicated by signals in the ${ }^{27} \mathrm{Al} \mathrm{NMR}$ at $\delta^{27} \mathrm{Al}=102.9,104.4,107.4$ ).

(40) Kuhn, N.; Kratz, T. Synthesis of Imidazole-2-ylidenes by Reduction of Imidazole-2(3H)-thiones. Synthesis 1993, 561-562.

(41) Bos, K. D.; Bulten, E. J.; Noltes, J. G.; Spek, A. L. Cyclopentadienyltin(II) halides. A novel type of divalent organotincompounds. J. Organomet. Chem. 1972, 39, C52-C54.

(42) Bos, K. D.; Bulten, E. J.; Noltes, J. G.; Spek, A. L. The crystal and molecular structure of cyclopentadienyltin(II) chloride. The bonding of the cyclopentadienyl group in tin(II) compounds. J. Organomet. Chem. 1975, 99, 71-77.

(43) Müller, C.; Andrada, D. M.; Bischoff, I.-A.; Zimmer, M.; Huch, V.; Steinbrück, N.; Schäfer, A. Synthesis, Structure, and Bonding Analysis of Tin(II) Dihalide and Cyclopentadienyltin(II) Halide (Alkyl)(amino)carbene Complexes. Organometallics 2019, 38, 10521061.

(44) Sheldrick, G. M. A short history of SHELX. Acta Crystallogr., Sect. A: Found. Crystallogr. 2008, 64, 112-122. 